\title{
Aspartate aminotransferase to platelet ratio index and blood platelet count are good markers for fibrosis evaluation in schistosomiasis mansoni
}

\author{
O índice da relação aspartato aminotransferase sobre plaquetas e a \\ contagem de plaquetas no sangue são bons marcadores \\ de fibrose na esquistossomose mansônica
}

\section{Dear Editor:}

The assessment of periportal fibrosis is of major importance in determining strategies, prognosis and risk for complications in schistosomiasis mansoni ${ }^{3}$. For the last 2 decades, abdominal ultrasound has been used as the gold standard for the evaluation of liver fibrosis in schistosomiasis mansoni ${ }^{24}$, because hepatic biopsy has been shown to have low sensitivity in diagnosing advanced schistosomiasis ${ }^{1}$.

However, ultrasound has disadvantages: 1. it is expensive; 2. it takes several months of training for the examiner to learn and apply WHO's protocol for ultrasound in schistosomiasis; 3 . it is a subjective procedure and, thence, examiner-dependent. It would be of interest to find a non-invasive, simpler routine laboratory test, to accurately evaluate liver fibrosis in schistosomiasis mansoni.

In the last 5 years several non-invasive indexes have been proposed for predicting the degree of fibrosis in viral hepatitis. The aspartate aminotransferase to platelet ratio index (APRI) was found to exhibit a high degree of accuracy in identifying presence of significant fibrosis and cirrhosis in patients with chronic hepatitis $\mathrm{C}^{5}$. APRI is obtained using the following formula:

$$
\text { APRI }=\frac{\text { AST level/ULN }}{\text { Platelet counts }\left(10^{3} / \mathrm{mm}^{3}\right)} \times 100
$$

where AST is the value of aspartate aminotransferase measured in serum by a routine technique, ULN stands for upper limit of normal for aspartate aminotransferase, divided by blood platelet count, times 100 .

We applied APRI and blood platelet count in 47 patients with hepatosplenic schistosomiasis confirmed by ultrasound (Group 1) and in 13 controls with hepatointestinal schistosomiasis (Group 2). APRI (mean \pm SD) was $1.72 \pm 1.20$ and $0.34 \pm 0.22$ for groups 1 and 2 , respectively $(\mathrm{p}=0.00)$. The area under the receiver operating characteristic curve (AUC - ROC) was 0.96
[95\% confidence interval (CI), $0.92-1.01$ ]. For significant fibrosis, an APRI threshold of 0.44 was $96 \%$ sensitive and $85 \%$ specific. APRI was able to differentiate the degree of fibrosis: values for absent, light, moderate, and intense fibrosis were $0.34 \pm 0.22,1.38 \pm 0.51$, $1.74 \pm 1.33$ and $1.96 \pm 0.94$, respectively $(\mathrm{p}=0.00)$.

Blood platelet counts $\left(\mathrm{mm}^{3}\right)$ were $60,426 \pm 39,285$ and $194,646 \pm 97,768$ for groups 1 and 2 , respectively $(p=0.00)$. The AUC - ROC was 0.96 (95\% CI, $0.91-1.01)$. For significant fibrosis, a platelet count threshold of $108,500 / \mathrm{mm}^{3}$ was $91 \%$ sensitive and $85 \%$ specific. Platelet count also differentiated the degree of fibrosis. Platelets for absent, light, moderate, and intense fibrosis were 194,646 \pm 97,768, 72,800 $\pm 24,289,61,601$ $\pm 43,721$ and 44,114 $\pm 18,861$, respectively $(\mathrm{p}=0.00)$.

We conclude that APRI and blood platelet count are promising, inexpensive, non-invasive markers of liver fibrosis in schistosomiasis mansoni and also help to define the degree of liver involvement. A comprehensive study, with a larger number of patients, is under way to confirm these preliminary results.

\section{REFERENCES}

1. Bogliolo L. The anatomical picture of the liver in hepato-splenic schistosomiasis mansoni. Annals of Tropical Medicine and Parasitolology 51:1-14, 1957.

2. LambertucciJR, Gerspacher-Lara R, Pinto-Silva RA, Barbosa MM, Teixeira R, Barbosa HF, Serufo JC, Rezende DF, Drummond SC, Rayes AA. The Queixadinha Project: morbidity and control of schistosomiasis in an endemic area in the northeast of Minas Gerais, Brazil. Revista da Sociedade Brasileira de Medicina Tropical 29: 127-135, 1996.

3. Lambertucci JR, Serufo JC, Gerspacher-Lara R, Rayes AA, Teixeira R, Nobre V, Antunes CM. Schistosoma mansoni: assessment of morbidity before and after control. Acta Tropica 77: 101-109, 2000.

4. Richter J, Domingues ALC, Barata CH, Prata AR, Lambertucci JR. Report on the second satellite symposium on ultrasound in schistosomiasis. Memórias do Instituto Oswaldo Cruz 96: 151-156, 2001.

5. Wai CT, Greenson JK, Fontana RJ, Kalbfleisch JD, Marrero JA, Conjeevaram HS, Lok AS. A simple noninvasive index can predict both significant fibrosis and cirrhosis in patients with chronic hepatitis C. Hepatology 38: 518-526, 2003.

\section{José Roberto Lambertucci' ${ }^{1}$, Luciana Cristina dos Santos Silva ${ }^{1}$ and Carlos Maurício Antunes}

\footnotetext{
1. Pós-graduação em Ciências da Saúde: Infectologia e Medicina Tropical, Faculdade de Medicina, Universidade Federal de Minas Gerais, Belo Horizonte, MG. Address to: Dr. José Roberto Lambertucci. Faculdade de Medicina da UFMG. Av. Alfredo Balena, 190, sala 169, 30130-100 Belo Horizonte, MG, Brasil.

e-mail: lamber@uai.com.br

Phone/fax: $55313248-9820$

Recebido para publicação em: 20/09/2007

Aceito em: 26/09/2007
} 